Pathophysiology

of Haemostasis and Thrombosis
Pathophysiol Haemost Thromb 2005;34:205-208

DOI: $\underline{10.1159 / 000092425}$

\title{
Gene Structures of Trocarin D and Coagulation Factor X, Two Functionally Diverse Prothrombin Activators from Australian Rough Scaled Snake
}

\author{
M. Abu Reza ${ }^{\text {a Sanjay Swarup }}{ }^{\text {a R. Manjunatha Kini }}{ }^{a, b}$ \\ ${ }^{a}$ Protein Science Laboratory, Department of Biological Sciences, Faculty of Science, \\ National University of Singapore, Singapore; ${ }^{b}$ Department of Biochemistry, VCU Medical Center, \\ Virginia Commonwealth University, Richmond, Va., USA
}

\section{Key Words}

Prothrombin activation - Factor $\mathrm{X} \cdot$ Hemostasis •

Snake venom $\cdot$ Exon-intron boundary

\begin{abstract}
Activation of prothrombin to thrombin is the key reaction in blood coagulation cascade. We have recently shown that Australian rough scaled snake, Tropidechis carinatus, possesses two parallel prothrombin activator systems. Trocarin $\mathrm{D}$, a venom prothrombin activator produced in the venom gland, plays an offensive role as a toxin, whereas factor $X$ is produced in the liver and plays a role in the hemostatic mechanism. These two proteins are structurally similar and have identical domain architecture. Because of the differences in their physiological roles, and tissue-specific expression, we determined the gene structure of these closely related proteins. Both the genes have eight exons similar to all mammalian factor $X$ genes. All the exon-intron boundaries of these two genes are at the same position and the splice junctions are almost identical. Partial sequencing of the introns shows that they share a very high degree of sequence identity indicating that the gene duplication is a recent event. Further studies on the characterization of these two genes particularly the promoter regions are in progress.
\end{abstract}

Copyright (C) 2005 S. Karger AG, Basel

\section{KARGER}

Fax +41613061234

E-Mail karger@karger.ch

www.karger.com
(C) 2005 S. Karger AG, Basel

$1424-8832 / 05 / 0345-0205 \$ 22.00 / 0$

Accessible online at:

www.karger.com/pht

\section{Introduction}

Blood coagulation is a highly synchronized event of sequential activation reactions of several coagulation factors and prothrombin activation is in the center of this cascade. This key step in the coagulation cascade is targeted by a number of exogenous factors including snake venom toxins [1,2]. Snake venoms are one of the richest sources of exogenous prothrombin activators $[2,3]$. A number of these prothrombin activators have been purified and characterized [3-7]. Depending on the cofactor requirement for the optimal activity, the snake venom prothrombin activators are classified into four groups, namely groups A, B, C and D [8]. We recently purified and characterized a number of group $\mathrm{D}$ prothrombin activators $[9,10]$. We showed that trocarin $\mathrm{D}$ from the venom of Tropidechis carinatus is a true structural and functional homologue of mammalian FXa with the same domain architecture. It has a light chain and a heavy chain linked together by a single disulfide bond. The light chain has an N-terminal Gla domain followed by two epidermal growth factor-like domains and the heavy chain contains a serine proteinases domain [9]. Further, trocarin D induces cyanosis and death in mice probably through disseminated intravascular coagulopathy [11]. Thus it is used as a toxin. 


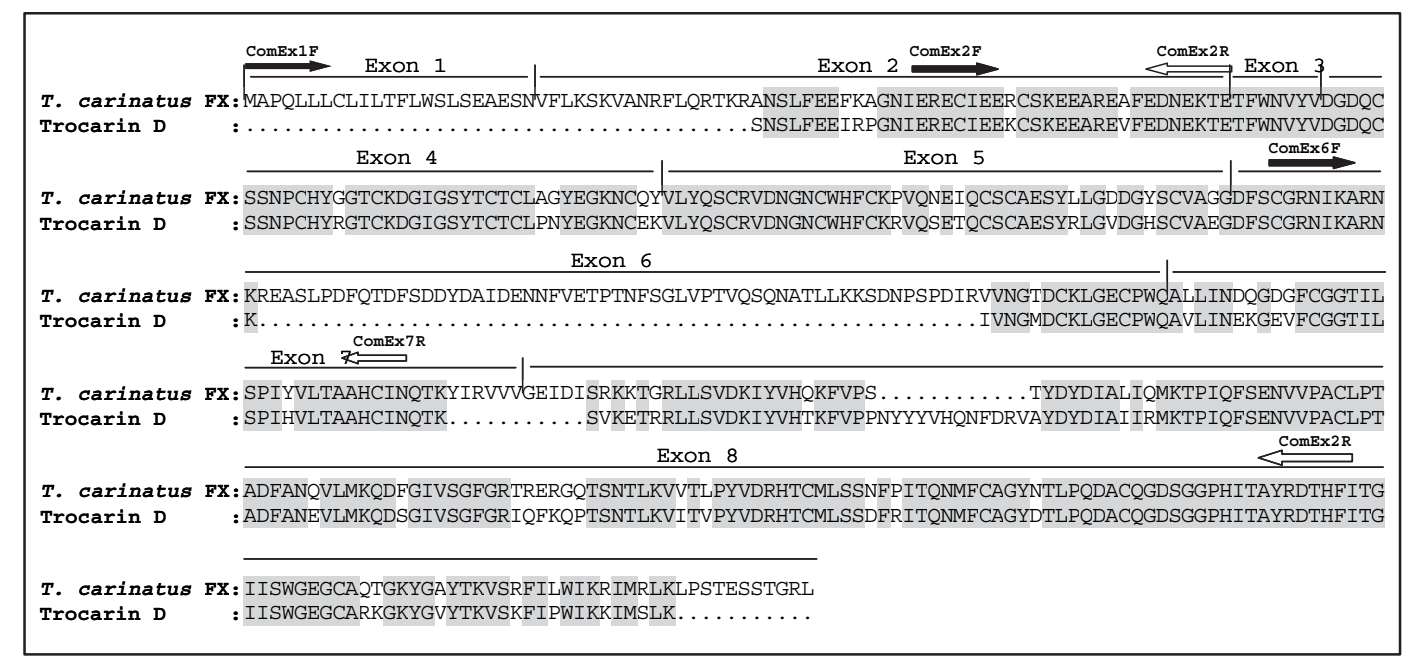

Fig. 1. Primer position for PCR amplification of FX and trocarin D gene of $T$. carinatus. Identical residues are shaded in grey. Exons are marked based on human FX gene structure. Position of sense primers are marked as solid forward arrows and the antisense primers are shown as hollow reverse arrows.

Like other vertebrates snakes have their own hemostatic system [12]. Our recent studies confirmed the production of the physiological prothrombin activator blood coagulation factor X (FX) in the liver of T. carinatus [13]. This FX shows significant structural similarity to trocarin D. Thus, in this snake two parallel prothrombin activating systems co-exist performing distinct physiological roles. The one in the blood is used as a hemostatic factor, whereas the other in the venom is used as an offensive weapon to target the prey's coagulation system. The regulation of expression of these highly similar prothrombin activators is distinctly different. FX is produced in the liver constitutively $[14,15]$ and hence produced at a steady-state level throughout its life. On the contrary, the expression of venom prothrombin activators is inducible $[16,17]$; when the venom gland is empty, its expression reaches maximum, and when it is full, its expression is slowed down or stopped. Moreover, the level of expression of trocarin $\mathrm{D}$ in the venom gland is very high $(\sim 1,150$ times) compared to FX in the liver [9]. Therefore, it is interesting to study the gene structure and regulation of expression of these closely related proteins. Here we present the complete gene structure of trocarin D and FX from $T$. carinatus by PCR of the genomic DNA (gDNA). This study is the first step towards the understanding of the regulation of expression of venom and blood prothrombin activators.

\section{Materials}

Liver of T. carinatus was purchased from the Venom Supplies Pty Ltd, Australia. DNeasy DNA extraction kit, Qiaquick gel extraction and PCR purification kit, QiaPrep mini prep kit were purchased from Qiagen (Valencia, Calif., USA). Long PCR Enzyme Mix was procured from Fermentas (Burlington, Ont., Canada), pGEMT Easy vector system was obtained from Promega corporation (Madison, Wisc., USA), The ABI PRISM ${ }^{\circledR}$ BigDye $^{\circledR}$ terminator cycle sequencing ready reaction kit was purchased from Perkin Elmer (Foster City, Calif., USA). Oligonucleotides were custom synthesized from 1st BASE (Singapore). All other chemicals and reagents were of the purest grade available.

\section{Methods}

\section{Genomic DNA Extraction}

Genomic DNA was extracted from T. carinatus liver tissue using the DNeasy ${ }^{\circledR}$ Tissue kit (Qiagen, USA) according to the manufacturer's instructions. For each extraction, $30 \mathrm{mg}$ liver tissue was taken. RNaseH was used during DNA extraction to remove any traces of contaminating RNA. Integrity of the isolated gDNA extracted was examined by $0.8 \%$ agarose gel electrophoresis and by checking the optical density.

\section{Isolation and Sequencing of Genomic Clones}

We used gDNA PCR to determine the gene structure of trocarin $\mathrm{D}$ and FX from T. carinatus. Trocarin D sequence [9] was aligned with the deduced amino acid sequence of $T$. carinatus FX [13] and the putative exon boundaries were marked (fig. 1) based on human and murine FX gene information $[18,19]$. Common sense and antisense primers for both the genes were designed from different exons(fig. 1) [ComEx1F1 (5'-ATGGCTCCTCAGCTACTCCTCT- 
3'-) and ComEx2R1 (5'-GGTCTCAGTTTTCTCGTTATCTTCAA-3') for exon 1 to exon 2, ComEx2F1 (5'-TTGAAAGGGAATGCATTGAGGAG-3') and ComEx7R (5'-TGGTTAATGCAGTGGGCT-3') for exons 2-7 and ComEx6F (5'-CATGTGGTAGAAATATAAAAGCAAGG-3') and ComEX8R (5'-GTAATAAAGTGGGTATCTCTGTATGC-3') for exons 6-8. The PCR reaction mix contained $0.25-0.50 \mu \mathrm{g}$ DNA as template and a final concentration of 1.5 U Fermentas long PCR enzyme mix, $1 \times$ PCR buffer, $15 \mathrm{~m} M \mathrm{MgCl}_{2}, 0.2 \mathrm{~m} M \mathrm{dNTP}$ mix and $0.2 \mu M$ primers in a total volume of $25 \mu \mathrm{l}$. The 3 -step thermal cycling involved a hot start at $94^{\circ} \mathrm{C} / 2 \mathrm{~min}$ followed by 34 cycles of $94^{\circ} \mathrm{C} / 1 \mathrm{~min}$, annealing temperature ranging from $50^{\circ} \mathrm{C}$ to $62^{\circ} \mathrm{C} / 40 \mathrm{~s}$ (depending on the primer $\mathrm{Tm}$ ), extension $68^{\circ} \mathrm{C}$ ranging from 3 to $8 \mathrm{~min}$ and a final extension of $68^{\circ} \mathrm{C} / 10 \mathrm{~min}$. The PCR products were fractionated on a $1.0 \%$ agarose gel and the band of interest was excised, purified and ligated into pGEMT-easy vector. At least 48 clones carrying the inserts were sequenced.

\section{Sequence Analysis}

Sequence analysis was carried out using BLASTX program at the National Centre for Biotechnology Information website (www. ncbi.nlm.nih.gov). Sequence alignment and translations were carried out using the GeneDoc or DNAMAN programs.

\section{Results}

\section{Cloning and Sequencing of Trocarin D and}

TrFX Gene

The long range PCR of gDNA was performed using gene specific primers for trocarin $\mathrm{D}$ and $T$. carinatus $\mathrm{FX}$ from different exons (fig. 1). We amplified the segments between exons 1 and 2, exons 2 and 7, and exons 6 and 8 of each gene. Amplification reactions produced almost same size of PCR products for each of the genes $(\sim 6, \sim 5$ and $\sim 3 \mathrm{~kb}$ size, respectively). The resultant PCR products were purified, cloned into pGEMT easy vector, and clones were partially sequenced. From each PCR reaction at least 48 clones were sequenced and similar sequences were grouped. Obtained nucleotide and deduced amino acid sequences matched either trocarin D or FX sequences. Analyses of both genes indicate the presence of 8 exons and 7 introns. All the exon-intron boundaries are same in both the genes.

\section{Discussion}

As shown earlier, there are two prothrombin activator systems in $T$. carinatus snake [13]. These prothrombin activators are structurally and functionally similar to each other, but perform different functions. Here, we have described the gene organization of FX and trocarin
Table 1. The exon-intron boundaries of $T$. carinatus FX and trocarin $\mathrm{D}$ gene

\begin{tabular}{|c|c|c|c|}
\hline Exon & Gene & 5'-Donor splice site & 3'-Donor splice site \\
\hline \multirow[t]{2}{*}{$1-2$} & FX & TAATGgtaag & tttagTATTC \\
\hline & Trocarin D & TAATGgtaag & tttagTATTC \\
\hline \multirow[t]{2}{*}{$2-3$} & $\mathrm{FX}$ & AAACTgtaag & atcagGAGAC \\
\hline & Trocarin D & AAACTgtaag & atcagGAGAC \\
\hline \multirow[t]{2}{*}{$3-4$} & $\mathrm{FX}$ & TGTAGgtaag & $\operatorname{gctagATGGG}$ \\
\hline & Trocarin D & TGTAGgtaag & gctagATGGG \\
\hline \multirow[t]{2}{*}{$4-5$} & $\mathrm{FX}$ & ATATGgtaag & catagTCTТА \\
\hline & Trocarin D & AAAAGgtaag & catagTCTТА \\
\hline \multirow[t]{2}{*}{$5-6$} & $\mathrm{FX}$ & TGGAGgtatg & ttcagGTGAC \\
\hline & Trocarin D & TGAAGgtatg & ttcagGTGAC \\
\hline \multirow[t]{2}{*}{$6-7$} & $\mathrm{FX}$ & GGCAGgtaaa & tttagGCACT \\
\hline & Trocarin D & GGCAGgtaaa & tttagGCAGT \\
\hline \multirow[t]{2}{*}{$7-8$} & $\mathrm{FX}$ & TGTAGgtgaa & agtagGGGAA \\
\hline & Trocarin D & TGTAGgtggg & cacagGGGAA \\
\hline
\end{tabular}

Exon sequences are shown in uppercase and the introns in lowercase. 'gt' and 'ag', the characteristic of a splice-donor and -acceptor site, respectively, are marked as bold.

D from T. carinatus. As with human and fish FX genes, both FX and trocarin D genes are organized into eight exons and intervened with seven introns. All the exonintron boundaries follow the GT-AG rule of splice-donor and -acceptor site in both the genes. Intron sequences adjacent to the splice-donor and -acceptor sites are also identical in both the genes except for intron seven (table 1). High sequence identity in the DNA and protein level, similar gene structure, and almost identical splice sites in these two diverse prothrombin activators strongly indicate a recent gene duplication event. Thus, we conclude that group D venom prothrombin activators have evolved by a recent duplication of liver FX gene and subsequently recruited in the venom gland for tissue-specific expression and are used as toxin to capture the prey. Currently, we are studying the promoter region of these two closely related genes in order to understand their regulation of expression.

\section{Acknowledgement}

This work was supported by the Academic Research Grants from the National University of Singapore. 


\section{References}

1 Markland FS Jr: Snake venoms. Drugs 1997; 54(suppl 3):1-10.

2 Hutton RA, Warrell DA: Action of snake venom components on the haemostatic system. Blood Rev 1993; 7:176-189.

-3 Rosing J, Tans G: Structural and functional properties of snake venom prothrombin activators. Toxicon 1992;30:1515-1527.

4 Gao R, Kini RM, Gopalakrishnakone P: A novel prothrombin activator from the venom of Micropechis ikaheka: isolation and characterization. Arch Biochem Biophys 2002;408: $87-92$.

-5 Hasson SS, Theakston RD, Harrison RA: Cloning of a prothrombin activator-like metalloproteinase from the West African saw-scaled viper, Echis ocellatus. Toxicon 2003;42:629634.

-6 Silva MB, Schattner M, Ramos CR, Junqueirade-Azevedo IL, Guarnieri MC, Lazzari MA, Sampaio CA, Pozner RG, Ventura JS, Ho PL, Chudzinski-Tavassi AM: A prothrombin activator from Bothrops erythromelas (jararacada-seca) snake venom: characterization and molecular cloning. Biochem J 2003;369:129_ 139.

7 Speijer H, Govers-Riemslag JW, Zwaal RF, Rosing J: Prothrombin activation by an activator from the venom of Oxyuranus scutellatus (Taipan snake). J Biol Chem 1986;261:1325813267.
-8 Kini RM, Morita T, Rosing J: Classification and nomenclature of prothrombin activators isolated from snake venoms. Thromb Haemost 2001;86:710-711.

-9 Joseph JS, Chung MC, Jeyaseelan K, Kini RM: Amino acid sequence of trocarin, a prothrombin activator from Tropidechis carinatus venom: its structural similarity to coagulation factor Xa. Blood 1999;94:621-631.

10 Rao VS, Joseph JS, Kini RM: Group D prothrombin activators from snake venom are structural homologues of mammalian blood coagulation factor Xa. Biochem J 2003;369: 635-642.

11 Joseph JS, Thirumangalathu S, Tsang F, Wong FW, Kini RM: Trocarin, a blood coagulation factor Xa homologue from snake venom, causes inflammation and mitogenesis. Toxicon 2003;42:769-776.

12 Archer RK: The haemostatic mechanism in man and other animals; in Macfarlane RG (ed): Blood Coagulation in Non-Human Vertebrates. San Diego, Academic Press, 1970, pp 121-132.

13 Reza MA, Swarup S, Kini RM: Two parallel prothrombin activator systems in Australian rough-scaled snake, Tropidechis carinatus. Structural comparison of venom prothrombin activator with blood coagulation factor X. Thromb Haemost 2005;93:40-47.
14 Bahnak BR, Howk R, Morrissey JH, Ricca GA, Edgington TS, Jaye MC, Drohan WW, Fair DS: Steady state levels of factor X mRNA in liver and Hep G2 cells. Blood 1987;69:224230.

15 Miao CH, Leytus SP, Chung DW, Davie EW: Liver-specific expression of the gene coding for human factor X, a blood coagulation factor. J Biol Chem 1992;267:7395-7401.

16 Rotenberg D, Bamberger ES, Kochva E: Studies on ribonucleic acid synthesis in the venom glands of Vipera palaestinae (Ophidia, Reptilia). Biochem J 1971;121:609-612.

$\checkmark 17$ De Lucca FL, Haddad A, Kochva E, Rothschild AM, Valeri V: Protein synthesis and morphological changes in the secretory epithelium of the venom gland of Crotalus durissus terrificus at different times after manual extraction of venom. Toxicon 1974;12:361-368.

18 Leytus SP, Foster DC, Kurachi K, Davie EW: Gene for human factor X: a blood coagulation factor whose gene organization is essentially identical with that of factor IX and protein C. Biochemistry 1986;25:5098-5102.

19 Cooper A, Liang Z, Castellino FJ, Rosen ED: Cloning and characterization of the murine coagulation factor $\mathrm{X}$ gene. Thromb Haemost 2000;83:732-735. 